\title{
Perilaku Kewirausahaan Petani Kopi Arabika Gayo di Kabupaten Bener Meriah Provinsi Aceh
}

\section{Enterpreneurial Behavior of GayoArabicaCoffee Farmers in Bener Meriah Regency Aceh Province}

\author{
Ulya Zainura ${ }^{1}$, Nunung Kusnadi ${ }^{2}$, dan Burhanuddin ${ }^{2}$ \\ 1) Program Pascasarjana Departemen Agribisnis, Fakultas Ekonomi dan Manajemen Institut Pertanian Bogor, Bogor \\ 2) Departemen Agribisnis, Fakultas Ekonomi dan Manajemen Institut Pertanian Bogor, Bogor
}

\begin{abstract}
Gayo Arabica coffee is one of the commodities trading plantation sub-sector that has opportunities to increase national income and improve the farmers income. The management of these coffee plantations was still traditionally cultivated. Many factors were influence the pattern oftraditional plantation farming. Enterpreneurial factors determining the success or failure of farmers for adapting to the environmental changes. The research aimed to identify the characteristics of Gayo Arabica coffee farmers, also analyze internal and external factors that influence entrepreneurial behavior of Gayo Arabica coffee farmers also analyze the impact of entrepreneurial behavior towards farm business performance Gayo Arabica coffee. This research was conducted from May 2015 until June 2015 in Bener Meriah Regency. The data was obtained from interviews using a questionnaire. The samples were 120 respondents of Gayo Arabica coffee farmers. The respondents were selected by simple random sampling technique. Data analysis was performed using the LISREL 8.30 software, based on SEM method. The results showed that individual characteristics of Gayo Arabica coffee farmers in generalities were differents on the level of productive age, the majority of formal education level was high senior school graduates, have enough experiences, coffee farm as main source of livelihood, have limited a financials capital and lands owned were 0,5-1 hectares. Individual characteristics and environmental business of Gayo Arabica coffee farmers showed a positive and significant influence to entrepreneurial behavior, with coefficient value were 0,20 and 0,75, and t-test value were 2,77 and 9,93, respectively. While entrepreneurial behavior also showed a positive and significant influence to performance perspective Gayo Arabica coffee farm, with influence coefficient value was 0,98 and the t-test value was 16,91. Thus, an increase of entrepreneurial behavior will be improve performance perspective of Gayo Arabica coffee farm.
\end{abstract}

Keywords: Entrepreneurial behavior, Gayo Arabica coffee farmers, individual characteristic,structural equation models (SEM)

\begin{abstract}
Abstrak
Kopi Arabika Gayo merupakan salah satu komoditi perdagangan subsektor perkebunan yang mempunyai peluang dalam rangka memperbesar pendapatan Negara dan meningkatkan penghasilan petani. Pengelolaan perkebunan kopi rakyat ini diusahakan masih secara tradisional. Banyak faktor yang mempengaruhi pola usahatani perkebunan secara tradisional yang selama ini dilakukan.Faktor kewirausahaan menentukan berhasil tidaknya petani dalam menyesuaikan perubahan lingkungan. Sehingga tujuan dari penelitian ini adalah mengidentifikasi karakteristik petani kopi Arabika Gayo, dan menganalisis pengaruh faktor karakteristik individu petani (internal factor) dan lingkungan bisnis (external factor) terhadap perilaku kewirausahaan petani kopi Arabika Gayo serta menganalisis pengaruh perilaku kewirausahaan terhadap perspektif kinerja usahatani kopi Arabika Gayo. Penelitian ini dilakukan pada bulan Mei 2015 hingga bulan Juni 2015 di Kabupaten Bener Meriah. Data yang digunakan diperoleh dari hasil wawancara menggunakan kuesioner. Jumlah sampel yang digunakan sebanyak 120 responden petani kopi Arabika Gayo yang dipilih dengan teknik simple random sampling. Analisis data dilakukan menggunakan metode SEM dengan bantuan software LISREL 8.30. Hasil penelitian menunjukkan bahwa karakteristik individu (internal factor) petani kopi Arabika Gayo secara umum yaitu rata-rata berada pada tingkat usia produktif, tingkat pendidikan formal mayoritas lulusan SMA, memiliki pengalaman yang cukup, usahatani kopi sebagai sumber mata pencaharian utama, memiliki modal yang terbatas dan luas lahan yang dimiliki rata-rata 0,5-1 hektar. Karakteristik individu (internal factor) petani kopi Arabika Gayo berpengaruh positif dan signifikan terhadap perilaku kewirausahaan dengan nilai koefisien sebesar 0,20 dan nilai t-hitung sebesar 2,77 dan pengaruh lingkungan bisnis berpengaruh positif dan signifikan terhadap perilaku kewirausahaan dengan nilai koefisien 0,75 dan nilai t-hitung 9,93, serta perilaku kewirausahaan berpengaruh positif dan signifikan terhadap perspektif kinerja usahatani kopi Arabika Gayo dengan koefisien pengaruh 0,98 dan t-hitung 16,91, maka dengan adanya peningkatan perilaku kewirausahaan akan meningkatkan perspektif kinerja usahatani kopi Arabika Gayo.
\end{abstract}

Kata kunci: perilaku kewirausahaan,petani kopi Arabika Gayo, karakteristik individu, structural equation model (SEM) 


\section{Pendahuluan}

Kewirausahaan menjadi perhatian penting dalam perekonomian suatu bangsa. Kemajuan atau kemunduran suatu bangsa ditentukan oleh adanya wirausahawan. Kewirausahaan merupakan penggerak pertumbuhan ekonomi suatu bangsa. Casson et al., (2006), menyebutkan bahwa kewirausahaan dan pertumbuhan ekonomi memiliki hubungan yang sangat erat dan positif dimana peningkatan jumlah wirausaha menyebabkan peningkatan pertumbuhan ekonomi suatu Negara. Wirausaha merupakan inovator utama dan sebagai suatu kekuatan dibalik pembangunan ekonomi.

Sektor pertanian hingga kini masih menjadi andalan program pemerintah untuk meningkatkan kesejahteraan rakyat. Selama krisis ekonomi berlangsung prioritas kebijakan lebih besar diarahkan kepada penyelesaian krisis moneter sehingga kebijakan di sektor pertanian relatif kurang, namun demikian sektor pertanian masih tetap menunjukkan pertumbuhan positif dibanding sektor yang lain. Sektor pertanian merupakan sektor riil yang masih menjanjikan dalam upaya peningkatan kesejahteraan masyarakat, terutama para petani.Pembangunan sektor pertanian di era globalisasi harus bertumpu kepada sumberdaya manusia (SDM) berdaya yang bergerak dibidang pertanian sehingga dapat, mau dan mampu bersaing (Saragih, 2010). Sumberdaya manusia (SDM) sebagai subjek pembangunan terdiri dari orang-orang yang memiliki nilai-nilai, budaya dalam kapasitas yang berbeda antara satu dengan yang lain.

Salah satu sub sektor yang mempengaruhi persentase pertanian terhadap Produk Domestik Bruto (PDRB) adalah sektor perkebunan. Pembangunan pertanian subsektor perkebunan mempunyai arti penting dan strategis terutama di Negara yang sedang berkembang, yang selalu berupaya; (1) memanfaatkan kekayaan sumberdaya alam secara lestari dan berkelanjutan, dan (2) memanfaatkan ilmu pengetahuan dan teknologi untuk menghasilkan produksi perkebunan dan bahan baku industri. Selain mempengaruhi tingkat PDB, perkebunan juga merupakan sub sektor yang membantu pendapatan devisa Negara dari hasil perkebunan yang di ekspor ke Negara tujuan. Selain dari segi ekonomi yang membantu pendapatan devisa Negara, sektor perkebunan juga sangat berpengaruh dari segi sosial yaitu dalam penyerapan tenaga kerja. Penyerapan tenaga kerja berdasarkan hasil pengusahaan maupun sebagai tenaga kerja murni dipengaruhi berdasarkan komoditi perkebunan yang dikelola.

Kopi merupakan salah satu komoditi perdagangan subsektor perkebunan yang mempunyai peluang untuk dikembangkan dalam rangka usaha memperbesar pendapatan Negara dan meningkatkan penghasilan pengusaha dan petani. Pengembangan kopi di Indonesia dimulai sejak periode tahun 1960-an, dalam bentuk perkebunan rakyat. Kopi juga merupakan salah satu dari delapan komoditas utama perkebunan yang memiliki luas areal yang cukup besar serta menjadi komoditas ekspor yang sangat menjanjikan, dimana hanya dua jenis kopi yang banyak diusahakan yaitu kopi Robusta yang menguasai mayoritas luas tanam kopi di Indonesia serta kopi Arabika. Sebagai salah satu komoditas ekspor yang penting, kopi diharapkan mampu memberikan nilai tambah penerimaan devisa baik bagi Negara pada umumnya maupun untuk daerah sentra produksi khususnya. Menurut Yahmadi (2007), tanaman kopi di Indonesia tersebar terutama di Sumatera, Jawa, Bali, Sulawesi dan Nusa Tenggara sekitar 95\% dari luas areal tersebut merupakan tanaman kopi rakyat, sedangkan tanaman kopi perkebunan sebagian besar terdapat di Jawa Timur dan Jawa Tengah.

Salah satu daerah penghasil utama kopi Indonesia adalah Provinsi Aceh, setelah Provinsi Sumatera Selatan dan Lampung. Pada tahun 2012 produksi kopi di Provinsi Aceh sebesar 54 ribu ton per hektar, namun pada tahun 2013 produksi kopi di Provinsi Aceh ini mengalami penurunan sebesar 48 ribu ton per hektar.Menurut SCAA (Specialty Coffee Association of America) kopi Arabika Gayo tergolong kopi specialti.Aroma khas dengan perisa (flavor) kompleks dan kekentalan (body) yang kuat, menjadikan kopi Arabika Gayo sebagai kopi berkualitas tinggi yang sangat diminati oleh pasar kopi dunia (ICCRI, 2008). Selain itu, sekitar 70\% kopi Arabika Gayo di Kabupaten Bener Meriah telah mendapatkan sertifikat produk yang berprinsip pada sistem pertanian berkelanjutan seperti Organic certified,Fairtrade dan Raintforest (Disbun Provinsi Aceh, 2013). Berbagai atribut produk yang telah melekat pada kopi Arabika Gayo memberikan keuntungan besar bagi pengembangan agribisnis kopi Arabika Gayo di Kabupaten Bener Meriah.

Berdasarkan hal ini, agar peran kopi Arabika Gayo sebagai asset daerah berperan penting, maka perkembangan yang cukup pesat ini perlu di dukung oleh teknologi dan sarana pasca panen yang 
cocok dengan kondisi petani, agar mereka mampu menghasilkan biji kopi yang sesuai dengan Standar Nasional Indonesia (SNI). Adapun biji kopi yang dihasilkan oleh petani hanya dapat dipasarkan dalam bentuk mentah atau bentuk cherry, sehingga perlu adanya penganekaragaman atau diversifikasi produk olahan kopi. Demikian halnya menurut Yusnadi (1992), menyatakan bahwa dalam pengembangan perkebunan kopi rakyat ini adalah sebagian besar dari petani kopi yang dalam pengelolaannya masih dibatasi oleh kemampuan yang mereka miliki, dalam arti dilakukan secara tradisional serta turun-temurun dan hanya sebagian kecil yang mengikuti perkembangan teknologi pertanian, sedangkan tingkat adopsi inovasi petani kopi dalam pengembangannya masih tergolong sedang. Artinya, petani belum secara penuh mengikuti pola perkebunan rakyat.

Petani sebagai pemilik usahatani yang mengambil keputusanakan perubahanatauinovasiyang disarankan untuk usahataninya. Lebih lanjut, Mosher (1997) mengungkapkan bahwa petani membuat suatu keputusan atas dasar demi kepentingan keluarganya dan dalam pengaruh anggota keluarganya terhadap dirinya, karena ketergantungan keluarga pada hasil usahatani, maka anggota keluarga mungkin mendesak petani untuk mengambil keputusan tertentu atau melakukan teknik tertentu. Hal ini menunjukkan bahwa dalam proses pengambilan keputusan petani tidak dilakukan oleh pemikiran sendiri, melainkan terdapat faktor yang mempengaruhi keputusan terhadap usahataninya tersebut. Faktor pengambilan keputusan terhadap kinerja usahataninya didukung oleh faktor internal dan eksternal.Sehingga diperlukan perilaku kewirausahaan agar petani termotivasi untuk meningkatkan kuantitas dan kualitas produk yang dihasilkan dari usahataninya. Hal ini akan dapat tergambar dari perilaku petani kopi Arabika Gayo dalam pengelolaan usahatani kopinya dan hubungannya dengan budidaya, pengolahan hingga rantai pemasaran. Selanjutnya, perilaku petani kopi Arabika Gayo tersebut diperkirakan akan berhubungan erat terhadap karakteristik individu (internal factor) dan lingkungan eksternal (external factor) yang dimiliki oleh petani kopi yang menjadi dasar keinginannya dalam berusahatani. Hal ini dapat tergambar dari persepsi lembaga-lembaga terkait dalam usahatani kopi Arabika Gayo serta sejauhmana koordinasi antar instansi tersebut dapat berjalan dengan baik dalam rangka pengelolaan kopi Arabika Gayo tersebut.
Persepsi petani terhadap usahatani kopi Arabika hanya terpaku pada usaha cukup lama dan dikelola secara turun-temurun, akan tetapi aplikasi teknologi mulai dari teknis budidaya hingga pengolahan dan pemasaran yang efisien hasil kopi petani masih perlu ditingkatkan melalui perilaku kewirausahaan. Sejumlah rangkaian perilaku petani tersebut, menurut Popkin (1986), merupakan suatu tindakan yang rasional.Dikatakan rasional karena hanya petani itu sendiri yang secara pasti mengetahui perilaku yang tepat sesuai dengan harapan dan kebutuhannya. Selama ini petani yang menghasilkan produk olahan kopi hanya menggunakan modal sosial berupa jaringan kekerabatan baik dalam proses pengolahan, maupun pemasaran, sehingga jangkauan pasar juga kurang optimal. Perspektif petani terhadap unsur-unsur modal sosial yang sudah kuat dan dapat dijadikan modal dasar dalam penanganan kopi Arabika Gayo ini, serta pandangan petani terhadap modal sosial mana yang masih lemah sehingga perlu penguatan juga menjadi pokok kajian ini. Salah satunya yaitu dengan mengkaji karakteristik dan perilaku kewirausahaan petani dalam menjalankan usahatani kopi Arabika Gayo sehingga dapat meningkatkan kinerja usahatani kopi Arabika Gayo di Bener Meriah. Hal ini akan dapat tergambar dari perilaku kewirausahaan petani dalam pengelolaan usahatani kopi Arabika Gayo dalam hubungannya dengan kinerja serta keberlanjutan usahatani kopi tersebut.

Berbagai studi tentang kopi Arabika Gayo memperlihatkan terdapat permasalahan yang terkait kepada aspek kelembagaan (Adri, 1999), keunggulan bersaing (TM Silitonga, 2008), produksi dan efisiensi usaha tani (Fatma, 2011), sistem manajemen kualitas (Hasni, 2011), rantai pasok (Saputra, 2012), efisiensi pemasaran (Putri, 2013) dan keberlanjutan rantai pasok (Jaya, 2014).Namun, sedikit sekali studi tentang kewirausahaan petani, apalagi dikaitkan dengan kinerja usahataninya.Selama ini kinerja usahatani lebih banyak dikaitkan dengan aspek teknik budidaya.Kewirausahaan memiliki peranan yang sangat penting dalam peningkatan kinerja usahatani. Peningkatan kewirausahaan petani ditunjukan oleh adanya peningkatan semangat atau keinginan dan persepsi petani untuk semakin berhasil dalam menjalankan usahataninya. Oleh karena itu, motivasi utama penelitian ini adalah ingin membuktikan apakah kewirausahaan petani dapat dijadikan alaternatif pendekatan lain dalam peningkatan kinerja usahatani. 
Tantangan kedepan diantaranya adalah bagaimana respon petani kopi menghadapi permasalahan tersebut dengan meningkatkan perilaku kewirausahaan petani kopi yang berkaitan dengan kinerja usahatani kopi, kemampuan produksi dan keputusan investasi sehingga rumah tangga petani mampu mengurangi risiko. Dengan adanya kondisi seperti ini, maka yang menjadi perumusan masalah yaitu (1) bagaimanakah karakteristik individu petani kopi Arabika Gayo dalam menjalankan usahataninya?, (2) bagaimanakah pengaruh karakteristik individu (internal factor) dan lingkungan bisnis (external factor) terhadap perilaku kewirausahaan petani kopi Arabika Gayo? serta, (3) bagaimanakah pengaruh perilaku kewirausahaan terhadap kinerja usahatani kopi Arabika Gayo di Kabupaten Bener Meriah.

\section{Metode Penelitian}

Penentuan sampel dilakukan dengan metode simple random sampling dengan pembagian proporsi yang rata untuk setiap kecamatan.Metode ini dilakukan karena telah terdapat sampling frame untuk masing-masing kecamatan terpilih.Selanjutnya untuk menentukan jumlah sampel, dipilih 3 kecamatan yang memiliki jumlah petani kopi Arabika terbesar dari 10 kecamatan yang ada di Kabupaten Bener Meriah, yaitu Kecamatan Permata, Kecamatan Bandar dan Kecamatan Bukit.Berdasarkan data yang diperoleh petani yang menghasilkan produktivitas kopi Arabika Gayo terbesar pada 3 kecamatan tersebut adalah sebanyak 143 orang petani. Dari jumlah populasi diambil sampel secara acak dengan proporsi yang sama dari tiap kecamatan dan disesuaikan dengan kriteria pemilihan sampel. Sehingga, jumlah responden diperoleh sebanyak 120 responden, 50 orang petani berasal dari Kecamatan Permata, 45 orang petani berasal dari Kecamatan Bandar dan 25 orang petani berasal dari Kecamatan Bukit. Ferdinand (2002) menyebutkan bahwa untuk model SEM ukuran sampel yang sesuai adalah antara 100-200, dan pedoman ukuran sampel tergantung pada jumlah indikator kali 5 sampai 10.Bila terdapat 20 indikator, besarnya sampel adalah antara 100-200.Untuk penelitian ini, maka jumlah sampel yang diambil adalah sebanyak 120 responden.

\section{Metode Pengolahan dan Analisis Data}

Dalam penelitian ini,metode dan analisis yang digunakan adalah metode kuantitatif.Data dalam penelitian ini dianalisis dengan menggunakan metode Structural Equation Modelling (SEM) dengan program LISREL 8,30. Tahapan prosedur SEM diawali dengan tabulasi data hasil pengisian kuesioner dengan menggunakan MS Exel 2010, kemudian di analisis dengan metode SEM dengan tahapan (1) spesifikasi model; (2) identifikasi model; (3) estimasi model; (4) uji validitas dan reliabilitas; (5) uji kecocokan model dan (6) respesifikasi model (Ferdinand, 2002).

\section{Variabel Penelitian dan Skala Pengukuran}

Variabel penelitian merupakan konsep yang memiliki nilai dan dapat diukur. Variabel-variabel yang akan digunakan dalam penelitian ini terdiri atas variabel laten dan variabel manifes (indikator dari variabel laten). Adapun laten eksogen karakteristik individu petani kopi Arabika Gayo yang akan diteliti pada penelitian ini diantaranya pendidikan, pengalaman, motivasi berusahatani, persepsi terhadap usahatani, dan keinginan berusahatani. Sedangkan laten eksogen faktor lingkungan bisnis diantaranya ketersediaan bahan input, dukungan penyuluhan dan pelatihan, bantuan modal usaha, dukungan promosi dan pemasaran, dukungan regulasi usaha, kekompakan petani dan akses terhadap informasi pasar. Indikator bagi laten endogen perilaku kewirausahaan adalah inovatif, berani mengambil resiko, tekun berusaha, tanggap terhadap peluang dan bersikap mandiri. Indikator laten endogen perspektif kinerja usahatani yang digunakan adalah tingkat pendapatan, perluasan wilayah pemasaran, kemampuan bersaing dan komitmen dalam berusahatani (Puspitasari, 2013; Delmar, 1996; Priyanto, 2009; Burhanuddin, 2014; Fereidouni et al., 2010; Kasmir, 2006; Kumar, 2003; Ucbasaran et al., 2005; Rauch dan Frese, 2007; dan Sumantri, 2013).

Pengumpulan data melalui kuesioner dilakukan dengan wawancara tatap muka. Setiap variabel manifes diindikasikan oleh beberapa pernyataan dan setiap pernyataan dalam kuesioner diberi skala dengan menggunakan skala Likert 1-5 dengan penjelasan sebagai berikut:

1. = sangat tidak setuju dengan pernyataan dalam kuesioner dan tidak pernah melakukan kegiatan yang ada dalam pernyataan pada kuesioner

2. = tidak setuju dengan pernyataan dalam kuesioner dan jarang melakukan kegiatan yang ada dalam pernyataan pada kuesioner 
3. = netral dengan pernyataan dalam kuesioner dan kadang-kadang melakukan kegiatan yang ada dalam pernyataan pada kuesioner

4. = setuju dengan pernyataan dalam kuesioner dan sering melakukan kegiatan yang ada dalam pernyataan pada kuesioner

5. = sangat setuju dengan pernyataan dalam kuesioner dan selalu melakukan kegiatan yang ada dalam pernyataan pada kuesioner

\section{Hasil dan Pembahasan}

\section{Gambaran Umum Karakteristik Petani Kopi Arabika Gayo}

\section{Sebaran Responden Berdasarkan Usia}

Sebagian besar petani kopi Arabika Gayo yang menjadi responden berada pada kisaran usia yang masih produktif, dimana $55 \%$ dari responden berada pada kisaran usia 41 - 56 tahun, dan disusul oleh responden pada kisaran usia 25 - 40 tahun sebanyak $33 \%$. Sedangkan 9\% diantaranya sudah berumur diatas 56 tahun dan hanya 3\% yang berumur di bawah 25 tahun. Menurut Riyanti (2003), perkembangan karir berjalan seiring dengan proses perkembangan manusia, yang mengelompokkan perkembangan karir manusia menjadi tiga kelompok manusia, yaitu (1) usia dewasa, awal antara 18 sampai 40 tahun, ciri khasnya terkait dengan tugas pengembangan dalam membentuk keluarga dan pekerjaan, memiliki tugas pokok, memilih bidang pekerjaan yang cocok dengan bakat, minat dan faktor psikologis yang dimiliki sehingga kesehatan mental dan fisiknya tetap terjaga; (2) usia dewasa madya antara 40 sampai 60 tahun, ciri khasnya keberhasilan dalam pekerjaan. Keberhasilan itu biasanya dicapai pada usia empat puluh dan lima puluh, pada usia ini kebanyakan mencapai prestasi puncak, memiliki pekerjaan yang lebih baik dibanding dengan pekerjaan yang dimiliki ketika masih muda; (3) usia dewasa akhir di atas 60 tahun, pada masa ini mulai mengurangi kegiatan karirnya, karena menurunnya kesehatan dan fisik, lebih banyak melakukan kegiatan sosial dan menikmati hasil jerih payah selama bekerja. Jika dilihat berdasarkan banyaknya petani kopi arabika yang menginjak usia dewasa madya $(54,1 \%)$, maka seharusnya petani tersebut sudah mencapai prestasi puncak, atau sudah mencapai keberhasilan dalam menjalankan usahatani kopi Arabika Gayo. Petani dalam kisaran usia produktif tersebut masih potensial untuk mengembangkan diri dan mengembangkan usahataninya. Disamping itu, komposisi umur petani tersebut menunjukkan bahwa usahatani kopi arabika masih merupakan sumber mata pencaharian yang menarik bagi tenaga kerja usia produktif di wilayah penelitian.

\section{Sebaran Responden Berdasarkan Pendidikan Formal}

Tingkat pendidikan formal responden sebagian besar adalah lulusan SMU, yaitu mencapai 54\%. Tingkat pendidikan diharapkan dapat berpengaruh terhadap tingkat adopsi teknologi yang dapat memperbaiki pengelolaan usahatani baik dari teknis budidaya hingga pascapanen dan teknik pemasaran. Pendidikan formal yang lebih tinggi akan sangat berperan dalam kemampuan menganalisis berbagai situasi, wawasan berpikir dan pemanfaatan teknologi terkini.Menurut Welter dan Smallbone (2011), seorang wirausaha dengan modal pendidikan dan pengetahuan yang memadai dapat lebih mudah beradaptasi dengan lingkungannya. Dengan pendidikan, wirausaha dapat mengeksploitasi peluang, juga akan lebih mudah menyesuaikan diri dengan struktur kelembagaan yang berubah-ubah, mereka dapat lebih mudah membangun kontak bisnis dan membangun jaringan sosial untuk mengatasi hambatan dalam kelembagaan. Demikian halnya pendapat Hadiati (2007) yang menyatakan bahwa pendidikan dapat lebih memperluas interaksi. Keberadaan petani dengan tingkat pendidikan yang lebih tinggi diharapkan mampu menjadi pembimbing bagi petani lain yang tingkat pendidikan dan pengetahuannya lebih rendah. Tingkat pendidikan dapat menentukan kualitas kinerja seseorang, khususnya dalam mencerna informasi.

\section{Sebaran Responden Berdasarkan Pengalaman}

Petani kopi Arabika Gayo rata-rata memiliki pengalaman 5-10 tahun sebanyak 35\%. Hal ini menunjukkan para petani tersebut sudah cukup berpengalaman dalam menjalankan usahatani kopi arabika, baik dari proses budidaya hingga pemasaran, dengan demikian lebih berpeluang untuk mengembangkan usahanya untuk mencapai keberhasilan. Petani dengan pengalaman lebih dari dua puluh lima tahun menempati urutan kedua 
terbanyak, hal ini menunjukan banyaknya petani yang meneruskan usahatani kopi arabika dari orangtua ataupun turun-temurun, dan juga adanya petani-petani yangberusahatani kopi arabika dari mulai sejak usia sepuluh tahun.

Kemampuan sumberdaya manusia (SDM) petani kopi Arabika Gayo umumnya didasarkan pada pengalaman bekerja (learning by doing) di lingkungan keluarga dan tetangga yang mengusahakan kopi arabika.Karena sebagian besar usahatani kopi arabika ini merupakan tanaman perkebunan dengan luasan yang besar, dan merupakan usaha turun-temurun, sehingga petani dibantu oleh keluarga dan sebagian besar dilakukan oleh petani seorang diri.Dengan demikian dalam hal ketersediaan sumberdaya manusia atau tenaga kerja untuk berusahatani kopi arabika dirasa sudah cukup memadai. Dari hasil wawancara dilapangan, didapat $47 \%$ responden memilih tidak memiliki sumberdaya manusia (pegawai) lain, yaitu cukup dengan kebutuhan dengan kondisi yang cukup terampil yang dimiliki keluarganya, sedangkan beberapa responden merasa jumlah tenaga kerja keluarga yang ada saat ini tidak memadai dalam hal jumlah, namun mereka tidak memiliki cukup biaya untuk menggaji tambahan tenaga.

\section{Sebaran Responden Bersasarkan Luas Lahan}

Luas lahan usahatani kopi Arabika Gayo yang dimiliki petani hanya pada kisaran 0,5-1 hektar (40\%), kemudian disusul pada kisaran kurang dari 0,5 hektar (39\%). Hal inimenunjukkan bahwa umumnyausahatani kopi Arabika Gayo masih diusahakan pada skala usaha yang kecil, yang pada akhirnya dapat berimbas pada pendapatan. Kopi Arabika Gayo memiliki potensi yang sangat besar, namun lahan pertanamannya semakin terbatas, diantaranya dikarenakan banyaknya alih fungsi lahan dan potensi pengembangan lahan yang semakin berkurang. Dengan dicanangkannya kopi Arabika Gayo sebagai ikon daerah Gayo khususnya Kabupaten Bener Meriah, diharapkan usahatani kopi Arabika akan tetap bertahan dan berkembang sebagai sumber mata pencaharian bagi masyarakat di daerah tersebut.

\section{Sebaran Responden Berdasarkan Pendapatan}

Sumber pendapatan utama petani kopi Arabika Gayo di Kabupaten Bener Meriah adalah sebagai petani kopi, sedangkan pendapatan tambahan umumnya adalah bertani sayuran, pedagang dan peternak.Namun dari sisi pendapatan yang diperoleh dari usahatani kopi Arabika Gayo, rata-rata pendapatan yang paling banyak dalam kisaran Rp. 2.100.000-Rp. 3.000.000 per panen yang mencapai $57 \%$ dari total responden, diikuti dengan petani yang berpendapatan Rp. 1.000.000-Rp. 2.000 .000 per panen yang mencapai $41 \%$.

Sebagian besar petani mengakui bahwa usaha ini merupakan sumber pendapatan utama keluarga. Namun dengan penghasilan tersebut hanya cukup untuk mencukupi kebutuhan sehari-hari, dan sangat sulit untuk menyisihkan sebagai tambahan modal.Namun demikian, umumnya para petani kopi Arabika Gayo, tidak hanya mengusahakan kopi arabika, tetapi mereka mengusahakan pula tanaman hortikultura seperti cabai, kentang, kol dan sebagainya. Sebagaimana menurut Frederike dan Smallbone (2011) menyebutkan bahwa diversifikasi dari suatu usaha dapat berupa kegiatan tambahan dalam perdagangan atau jasa, kegiatan tambahan tersebut dapat berkontribusi untuk membiayai kegiatan utama bisnis dalam situasi dimana akses untuk mendapatkan modal eksternal langka, sedangkan kondisi penjualan berfluktuasi dan tidak pasti. Sebagian kecil petani kopi Arabika Gayo ada juga yang menambah penghasilan dengan menjalani profesi yang lain, seperti menjadi buruh bangunan.

Hasil pengamatan di wilayah penelitian menunjukkan bahwa, meskipun dengan berbagai keterbatasan, tantangan dan kesulitan yang dihadapi, petani-petani kopi Arabika Gayo tersebut tetap berusaha menekuni usahatani kopi Arabika Gayo dari sejak turun-temurun meskipun harus bersaing dengan pasar global, dengan demikian dibutuhkan perhatian pemerintah dalam pengembangan usahataninya.

\section{Karakteristik Individu (Internal Factor) Petani Kopi Arabika Gayo}

Karakteristik individu petani kopi Arabika Gayo (internal causality) merupakan atribut yang melekat pada sifat dan kualitas pribadi atau personal yang diperlihatkan dalam menjalankan usahanya. Analisis karakteristikpetani kopi Arabika Gayo diperoleh dari hasil perhitungan hasil wawancara dengan penilaian menggunakan skala likert 1 sampai 5. Dasar analisis karakteristik individu petani ini di dasarkan pada lima variabel yaitu pendidikan, pengalaman, motivasi berusahatani, persepsi terhadap 
usahatani dan keinginan berusahatani (Puspitasari 2013). Nilai-nilai dari kelima variabel tersebut yang dijadikan sebagai ukuran pengelompokkan responden memiliki karakteristk individu kewirausahaan yang tinggi, sedang atau rendah.

\section{Pendidikan}

Berdasarkan hasil wawancara dilapangan, menyatakan bahwa pendidikan petani kopi Arabika Gayo cukup bagus. Hal ini terlihat dari jawaban responden setuju yang berarti sering melakukan hal-hal pada beberapa pernyataan yaitu: $0,83 \%$ dari responden menganalisa masalah sebelum mengambil keputusan, $60 \%$ selalu aktif dalam berdiskusi, $0,83 \%$ memiliki pola pikir kreatif dengan cara sering mencoba ide baru seperti pengolahan kopi dalam rangka mencari bagaimana mengembangkan produk kopi dan meningkatkan kualitas kopi yang dihasilkannya dan 13,33\% mampu melihat potensi lingkungan kira-kira apa yang bisa dilakukan. Namun untuk mengemukakan ide atau pendapat $25 \%$ menjawab netral yaitu hanya dilakukan kadang-kadang karena untuk mengemukakan ide memerlukan keahlian bagaimana ide kita bisa dipahami oleh banyak orang.

Memperhatikan tingkat pendidikan responden sebagian besar adalah lulusan SMA, tingkat pendidikan diharapkan dapat berpengaruh dalam mengembangkan kemampuan berpikir untuk mengelola usahataninya dan meningkatkan pendapatan mereka.Menurut Dirlanudin (2010) bahwa pendidikan pada hakekatnya adalah untuk mengubah perilaku agar mampu melaksanakan kegiatan-kegiatan tertentu yang dikehendaki.Kegiatankegiatan tersebut umumnya dimaksudkan untuk mampu memecahkan masalah-masalah yang dihadapi demi terpenuhinya kebutuhan keinginan yang dirasakan.

\section{Pengalaman}

Petani dalam menjalankan usahatani kopi Arabika Gayo terlihat berpengalaman. Hal ini terlihat darijawaban responden setuju semua terhadap beberapa pernyataan yaitu $59 \%$ berasal dari keturunan yang juga pengusaha dan mempunyai usahatani kopi dari turuntemurun, $14 \%$ sering melakukan pemangkasan, $14 \%$ belajar dari kesuksesan oranglain, dan 2,5\% sering melakukan pengolahan biji kopi.

Petani kopi Arabika Gayo menyatakan bahwa pengalaman menjadi salah satu faktor utama dalam menjalankan usahatani ini. Karena tanaman kopi yang mereka miliki sebagian besar berasal sejak dari turun temurun dan mengandalkan pengalaman dalam hal pengelolaannya. Sejalan dengan penelitian Riyanti (2003), yang menyatakan bahwa wirausaha yang memiliki pengalaman dalam menjalankan usaha yang sama sebelumnya akan lebih mampu melihat peluang bisnis baru daripada seseorang yang berkarir pada usaha yang berbeda.

\section{Motivasi Berusahatani}

Berdasarkan banyaknya responden yang memilih jawaban setuju (60\%) dan netral $(30,83 \%)$, dapat dikatakan bahwa petani memiliki motivasi yang tinggi untuk menjadi petani kopi Arabika yang sukses. Adanya motivasi dapat mengarahkan perilaku pada tujuan tertentu.Motivasi yang timbul akibat kecenderungan ini meningkatkan kemandirian dan mengembangkan kreativitas (Irwanto et al., 1996). Sehingga dengan adanya motivasi untuk menjadi petani kopi Arabika yang sukses akan mendorong petani untuk mencapai suatu target dalam berusahatani, didukung dengan keberaniannya dalam menghadapi risiko berusaha dan selalu belajar dari kegagalan agar dapat meningkatkan kreativitas dan inovasinya.

\section{Persepsi terhadap Usahatani}

Persepsi terhadap keyakinan dan keberhasilan dalam berusahatani kopi Arabika, menunjukkan keyakinan yang tinggi. Hal ini ditunjukkan dari banyaknya responden yang memilih jawaban setuju (65\%).Berdasarkan data dilapangan, 55\% petani kopi Arabika Gayo menganggap usahatani ini menguntungkan dan memiliki prospek yang cerah.Adanya persepsi tersebutakanmampu meningkatkan kepercayaan diri petani untuk terus menekuni usahatani kopi Arabika. Hal ini tentunya perlu didukung oleh pemerintah setempat dengan menciptakan iklim yang kondusif bagi keberlangsungan usahatani kopi Arabika Gayo.Misalnya dengan menyediakan informasi mengenai preferensi konsumen seperti dari segi peningkatan kualitas dan informasi pasar, pemberian bantuan modal dan sarana/ prasarana bagi usahatani kopi tersebut.

\section{Keinginan Berusahatani Kopi Arabika Gayo}

Keinginan berusahatani kopi Arabika diukur melalui seberapa besar keinginan petani kopi Arabika Gayo untuk menjalani dan mempertahankan usahatani 
kopi ini. Dari hasil penelitian diketahuibahwa keinginan petani dalam berusahatani kopi Arabika cukup tinggi, hal ini dapat dilihat dari banyaknya responden yang memilih jawaban setuju (57,50\%).

Berdasarkan hasil pengamatan dilapangan, usahatani kopi Arabika Gayo ini merupakan pekerjaan utama yaitu merupakan sumber pendapatan keluarga bagi sebagian besar petani kopi (70\%), sedangkan sebagian lainnya menjadikan usahatani ini sebagai usaha sampingan dengan pekerjaan utama sebagai pedagang, buruh bangunan, Pegawai Negeri Sipil, petani cabai, petani kentang, petani kol, dan peternak.

\section{Lingkungan Bisnis Petani Kopi Arabika Gayo}

Lingkungan bisnis (external causality) merupakan faktor penyebab perilaku yang terdapat dalam lingkungan atau situasi. Indikator lingkungan bisnis diantaranya adalah; ketersediaan bahan input, penyuluhan dan pelatihan, bantuan modal dan saprotan, dukungan promosi dan pemasaran, dukungan regulasi usaha, kekompakkan petani kopi Arabika Gayo dan akses terhadap informasi pasar.

\section{Ketersediaan Bahan Input}

Ketersediaan bahan input seperti bibit, pupuk, pestisida dan lain sebagainya selama ini dianggap relatif mudah di dapatkan asalkan ada modal. Hal ini sesuai dengan hasil penelitian, dimana sebagian besar responden memilih jawaban setuju $(64,16 \%)$ dan netral (16,66\%). Kondisi ini dilapangan menunjukkan bahwa ketersediaan bibit umumnya didapatkan dari hasil generatif dan vegetatif atau didapatkan dari pedagang-pedagang bibit didaerah setempat serta dari koperasi.Hal ini dikarenak pembibitan tanaman kopi sangat mudah dilakukan, selain itu tanaman kopi dapat melakukan penyerbukan sendiri, hanya secara teknis budidaya yang masih kurang optimal.

\section{Dukungan Penyuluhan dan Pelatihan}

Persepsi petani terhadap dukungan pemerintah dalam kegiatan penyuluhan dan pelatihan bagi petani dirasa cukup memadai.Hal ini terlihat bahwa $65,83 \%$ petani menjawab setuju dan $21,50 \%$ petani menjawab sangat setuju. Dukungan pemerintah berupa penyuluhan dan pelatihan sudah pernah dirasakan oleh $60 \%$ petani kopi Arabika Gayo, berupa pelatihan cara pembuatan kompos, pengendalian hama dan pembibitan kopi Arabika. Namun demikian kegiatan penyuluhan dan pelatihan yang diberikan masih diseputar teknik budidaya, para petani berharap adanya pelatihan dan pendidikan mengenai pengolahan dan teknik dalam pemilihan bibit unggul.

\section{Bantuan Modal dan Sarana Produksi}

Persepsi petani terhadap bantuan modal dan sarana produksi dari pemerintah menunjukkan hasil yang cukup memadai. Hal ini ditunjukkan dari banyaknya responden yang memilih jawaban setuju $(61,67 \%)$. Selama ini perhatian pemerintah berupa bantuan modal usahatani belum rata dirasakan oleh petani.Petani sebagian masih sulit memperoleh sumber modal untuk meningkatkan produktivitas kopi mereka. Seperti dalam aktivitas pemeliharaan kopi, kopi yang dibudidayakan secara organik untuk mengatasi serangan hama dan penyakit maka tanaman kopi harus dilakukan pemangkasan. Keterbatasan sumberdaya yang ada baik modal maupun tenaga kerja menyebabkan petani akan meminjam uang kepada pedagang. Hal ini berdampak terhadap pilihan pemasaran petani, dimana petani harus menjual hasil panennya kepada pedagang yang telah meminjamkan uang.Berbeda kondisinya bagi perusahaan (eksportir), pihak perbankan memberikan akses pinjaman terhadap perusahaan yang dinilai layak untuk mendapatkan pinjaman. Atas dasar kepastian jaminan dan legalitas hukum yang terpenuhi, maka perbankan akan memberikan kredit kepada perusahaan dengan skala tertentu.

\section{Dukungan Promosi dan Pemasaran}

Dukungan promosi dan pemasaran dirasakan telah cukup memadai. Hal ini ditunjukkan dari banyaknya responden yang memilih jawaban netral $(21,66 \%)$ dan setuju (55\%). Dukungan tersebut dirasa telah cukup memadai dengan adanya Fairtrade yang dijual ke pasar Amerika Serikat.Pada sistem pemasaran kopi Arabika Gayo di Kabupaten Bener Meriah sebagian besar produksi kopi yang dihasilkan (80\%) dipasarkan ke pasar dunia.Oleh karena itu perusahaan ekspor kopi yang berasal dari Provinsi Aceh sebagian besar (87\%) memiliki sertifikat organik dan fairtrade dalam pemasaran kopi Arabika Gayo (AEKI 2013). 


\section{Dukungan Regulasi Usaha}

Dukungan pemerintah berupa regulasi usaha dirasakan cukup memadai. Hal ini ditunjukkan dari banyaknya responden yang memilih jawaban setuju $(65,83 \%)$. Salah satunya adalah masih banyaknya lembaga pemasaran yang terlibat dan adanya proses perubahan nilai tambah produk kopi yang dihasilkan yang akan mempengaruhi margin pemasaran yang diperoleh.

\section{Kekompakkan Petani Kopi Arabika Gayo}

Kekompakkan diantara petani kopi Arabika Gayo dirasa cukup memadai. Hal ini ditunjukkan dari banyaknya responden yang memilih jawaban setuju (73,33\%). Umumnya petani di daerah Kabupaten Bener Meriah tergabung dalam kelompok tani, mereka bekerjasama menghadapi permasalahan dan tantangan dalam berusahatani kopi Arabika Gayo untuk kemajuan bersama.

Budaya Aceh yang kuat dalam mufakat, gotongroyong dan adat minum kopi tentunya merupakan hal yang sangat baik an dapat menjadi pondasi yang kuat dalam pengembangan usahatani kopi Arabika Gayo.

\section{Akses Informasi Pasar}

Informasi pasar yang mengenai kondisi harga kopi di pasaran, informasi pasar ekspor, pasar domestik, syarat mutu (standart), dan kuantitas yang dibutuhkan dirasa cukup memadai. Dari hasil penelitian menunjukkan sebagian besar responden menjawab setuju $(64,16 \%)$.

Berdasarkan hasil dilapangan, didapatkan bahwa infromasi pasar sudah memadai namun keterbatasan petani dalam mengaksesnya seperti penggunaan teknologi informasi misalnya internet masih dirasa sangat kurang dan belum memadai. Namun demikian dari pengalamannya selama ini petani kopi Arabika Gayo umumnya sudah mengetahui harga dan syarat mutu yang dibutuhkan di pasaran melalui pedagang pengumpul (kolektor). Keberhasilan usaha ditentukan antara lain oleh kemampuan memenuhi kebutuhan konsumen dan pasar. Petani membutuhkan informasi tentang pasar ekspor dan kuantitas yang dibutuhkan, karena disitulah banyak terjadi permainan harga ditingkat petani.Umumnya petani memanfaatkan pedagang pengumpul dan petugas PPL sebagai informan dalam menjalankan usahataninya.Informasi tersebut dapat menjadi sumber inovasi dan strategi usahatani yang menguntungkan. Ketersediaan informasi mengenai peluang pasar dan harga merupakan salah satu cara agar petani memiliki posisi tawar menawar yang kuat.

\section{Perilaku Kewirausahaan Petani Kopi Arabika Gayo}

Berdasarkan hasil penelitian menunjukkan bahwa persepsi petani terhadap perilaku kewirausahaan secara keseluruhan memiliki kecenderungan yang tinggi.Persepsi petani pada perilaku mampu berinovasi, pengambilan risiko, tekun berusaha, tanggap terhadap peluang dan bersikap mandiri menunjukkan kecenderungan yang tinggi, hanya saja pada perilaku mampu inovasi masih menunjukkan hasil yang rendah.

\section{Inovatif}

Berdasarkan hasil penelitian menunjukkan persepsi petani terhadap perilaku inovatif cukup memadai. Hal tersebut ditunjukkan dengan sebagian besar petani memilih jawaban setuju (67,50\%). Umumnya petani kopi Arabika Gayo sangat ingin berinovasi dalam hal budidaya, dan pascapanen. Namun petani kopi Arabika Gayo masih beranggapan bahwa tanaman kopi Arabika miliknya merupakan usahatani turun-temurun dan tetap mempertahankan cara tradisional yang telah ditinggalkan dari turun-temurun. Disamping itu petani kopi Arabika Gayo di Kabupaten Bener Meriah umumnya belum mampu dan belum cukup berani untuk mengambil risiko dalam menerapkan inovasi baik dari segi budidaya, pemeliharaan maupun pengolahan.Padahal dengan adanya inovasi merupakan kunci dari keunggulan bersaing dan dapat meningkatkan pertumbuhan suatu usaha. Perilaku inovatif dianggap karakteristik utama dari kewirausahaan dibandingkan dengan karakteristik lain. Hal ini dikarenakan seorang wirausaha yaitu orangorang yang mau belajar dan mempraktekkan inovasi secara sistematis, yang oleh karenanya segala risiko yang mungkin terjadi telah diantisipasi jauh sebelumnya sehingga risiko justru berada dalam pengendalian (Krisnamurthi 2001).

\section{Pengambilan Risiko}

Pada dasarnya usaha dibidang pertanian 
memiliki risiko yang tinggi, karena terutama sangat tergantung pada kondisi cuaca dan serangan hama dan penyakit yang relati sulit di prediksi kemunculannya. Demikian juga dengan usahatani kopi Arabika Gayo mempunyai risiko yang cukup tinggi, baik dari sisi on farm maupun kepastian pasarnya.Berdasarkan hasil penelitian menunjukkan sebagian besar petani memilih jawaban setuju (70\%), dengan demikian persepsi petani terhadap perilaku berani mengambil risiko menunjukkan hasil yang cukup tinggi.Hal ini menunjukkan bahwa petani kopi Arabika Gayo dalam menjalankan usahatani ini sudah mampu memperhitungkan risiko yang mungkin timbul. Semakin lamanya pengalaman dalam mengelola usahatani kopi Arabika dapat menjadi pengetahuan dalam mengatasi risiko usaha tersebut.Bagi petani risiko yang timbul dalam menjalankan usahatani kopi Arabika ini dianggap masih wajar dan mampu diatasi oleh petani.

Berdasarkan survei menunjukkan sebagian besar petani menganggap tingkat kesulitan dalam menjalankan usahatani kopi Arabika ini tidak sulit, dan frekuensi permasalahan cukup jarang terjadi. Permasalahan tersebut terutama adalah faktor cuaca yang ekstrim, tingkat hama dan penyakit tanaman kopi yang tinggi, pengolahan, dan kualitas bibit.

\section{Tekun Berusaha}

Sebagaimana diketahui secara umum usahatani kopi Arabika Gayo merupakan usahatani yang membutuhkan ketekunan dalam merawat dari mulai bibit sampai panen dan pascapanen.Persepsi petani terhadap perilaku tekun berusaha menunjukkan hasil yang sangat baik. Hal ini ditunjukkan dengan mayoritas petani memilih jawaban setuju $(67,50 \%)$.

Perilaku ketekunan ini ditunjukkan dengan kegigihan menekuni usahatani kopi Arabika Gayo, serta kesabaran dalam menjalankan dan menghadapi kesulitan dalam berusahatani. Menurut para petani, dari mulai pembibitan sampai panen membutuhkan jangka waktu yang cukup lama yaitu 2 sampai 3 tahun, dan perawatan seperti pemangkasan dan pemupukan harus maksimal. Sehingga petani harus sabar merawatnya agar menghasilkan keuntungan disaat panen.

\section{Tanggap terhadap Peluang}

Persepsi petani terhadap perilaku tanggap terhadap peluang menunjukkan hasil yang baik. Hal ini ditunjukkan dengan sebagian besar petani memilih jawaban setuju (56,66\%). Berdasarkan hasil dilapangan menunjukkan petani kopi Arabika Gayo cukup tanggap terhadap peluang, namun hanya sebagian kecil yang mampu memanfaatkan peluang tersebut untuk mengembangkan usahatani mereka. Sikap tanggap terhadap peluang ini akan lebih berkontribusi terhadap perkembangan usahatani jika ditindaklanjuti dengan tindakan kreatif dan inovatif, serta keberanian dalam mengambil risiko usahatani.

Sikap tanggap terhadap peluang ditunjukkan petani dengan menanam varietas-varietas baru yang dianggap berkualitas dan disukai konsumen.Seperti varietas Longberry dan Honeyberry yang lagi populer di masyarakat, dengan rasa yang nikmat dan harga yang tinggi yang dibudidayakan petani. Selain itu beberapa petani pernah mengikuti pelatiahan cara pembuatan kompos dan sebagian petani pernah mengikuti ajang pameran uji rasa cita kopi. Kegiatan tambahan tersebut pada akhirnya dapat berkontribusi dalam situasi dimana akses untuk mendapatkan modal eksternal.

\section{Bersikap Mandiri}

Persepsi petani terhadap perilaku bersikap mandiri menunjukkan hasil yang cukup memadai. Hal tersebut berdasarkan data dilapangan bahwa sebagian besar petani memilih jawaban setuju (60,83\%). Kemandirian petani kopi Arabika ditunjukkan dengan perilaku mereka yang tidak berpangku tangan menunggu perhatian dan bantuan dari pemerintah setempat, justru dapat dikatakan keberadaan dan keteguhan petani untuk terus menekuni usahatani ini cukup baik, mereka bisa bertahan dengan kondisi modal yang terbatas, sarana dan prasarana yang terbatas, dan dengan pendapatan yang terbatas pula.

Berdasarkan hasil penelitian menunjukkan bahwa petani kopi Arabika Gayo sebenarnya telah menunjukkan perilaku kewirausahaan yang cukup tinggi, namun masih kurang kemampuannya dalam berinovasi.Hal ini karena petani umumnya mengikuti faktor kebiasaan dari turun-temurun, sehingga belum berani untuk menerapkan inovasi.Padahal perilaku inovatif merupakan hal yang penting dalam mencapai petani wirausaha yang sukses. Senada dengan hasil penelitian Runyan et al., (2008) tentang pengaruh Entrepreneurial Orientation (EO) dan Small Business Orientatition (SBO) terhadap usaha kecil. Dimana 
tujuan SBO berbeda dengan EO, pengusaha yang berorientasi kewirausahaan akan cenderung melakukan inovasi, baik dengan membuat barang baru, metode baru yang lebih efisien, membuka pasar baru, bersikap proaktif, dan berani mengambil risiko. Sedangkan pengusaha yang berorientasi SBO, memiliki preferensi yang kurang untuk melakukan inovasi, tidak aktif dalam pemasaran dan hanya berorientasi pada pemenuhan keluarga sehai-hari. Sehingga kinerja yang dihasilkan EO tentunya akan lebih baik dalam meningkatkan pendapatan perusahaan. dengan demikian dapat dikatakan bahwa petani kopi Arabika yang mempunyai EO adalah petani yang memiliki kemampuan manajerial, proaktif, tanggap terhadap peluang, serta inovatif, baik dalam budidaya, produksi maupun inovasi produk.

\section{Perspektif Kinerja Usahatani Kopi Arabika Gayo}

Perspektif kinerja usahatani pada penelitian ini direfleksikan atau diindikasikan oleh empat variabel yaitu peningkatan pendapatan, perluasan wilayah pemasaran, keunggulan bersaing dan komitmen berusahatani. Sementara perspektif kinerja usahatani pada penelitian ini yang dimaksud adalah pandangan petani terhadap kinerja usahatani kopi Arabika Gayo yang selama ini dijalankan. Perspektif kinerja dilihat dari bagaimana usahatani yang dijalankan dari segi pendapatan, wilayah pemasaran, mampu bersaing dipasaran, serta bagaimana kemampuan petani dalam bertahan dalam menjalankan usahatani kopi Arabika Gayo tersebut.

\section{Peningkatan Pendapatan}

Persepsi petani terhadap peningkatan pendapatan dari usahatani kopi Arabika Gayo menunjukkan kecenderungan yang cukup memadai. Hal ini ditunjukkan dari mayoritas responden memilih jawaban setuju (57,50\%). Adanya kecenderungan tersebut dapat menjadi indikasi semakin meningkatnya komitmen atau minat masyarakat dalam berusahatani kopi Arabika ternyata belum dapat meningkatkan pendapatan mereka. Berdasarkan keterangan di lapangan, bahwa keterbatasan kemampuan dan sulitnya permodalan menyebabkan petani kopi Arabika Gayo tidak mampu meningkatkan skala usahatani mereka, yang akhirnya berimbas pada jumlah produksi kopi Arabika Gayo yang cenderung stagnan.

\section{Meningkatnya Wilayah Pemasaran}

Berdasarkan data dilapangan menunjukkan bahwa mayoritas responden memilih jawaban setuju (70\%), sehingga dapat disimpulkan bahwa persepsi petani terhadap meningkatnya wilayah pemasaran kopi Arabika Gayo menunjukkan kecenderungan yang cukup meningkat. Adanya kecenderungan tersebut mengindikasikan bahwa semakin meningkatnya minat masyarakat terhadap kopi Arabika Gayo, serta semakin dikenalnya wilayah tersebut sebagai sentra penghasil kopi Arabika.

Sebagian besar penjualan hasil produksi petani kopi Arabika Gayo di Kabupaten Bener Meriah hanya dapat dilakukan melalui kolektor yang ditunjuk oleh koperasi. Hal itupun terjadi jika petani kopi tersebut terlibat dalam program sertifikasi produk. Pada proses pendistribusiannya, setiap pelaku pemasaran memiliki pilihan dalam memasarkan bentuk kopi mereka. Perbedaan bentuk ini disebabkan adanya proses pengolahan yang dilakukan. Di tingkat petani, terbatasnya alternatif saluran pemasaran disebabkan oleh keterikatan petani dengan kolektor. Secara institusi, koperasi merupakan lembaga yang menampung hasil kopi petani. Melalui kolektor, petani dapat menjual hasil panen kepada koperasi. Namun disisi lain, keterikatan pinjaman yang dilakukan petani dengan kolektor menyebabkan petani tidak dapat memasarkan kopinya selain kepada kolektor yang telah memberikan pinjaman. Kondisi ini menyebabkan posisi petani lemah dalam proses penentuan harga dan perluasan pangsa pasar.

\section{Keunggulan Bersaing}

Keunggulan bersaing dapat diartikan sebagai kemampuan dalam menciptakan nilai unggul suatu produk guna menghadapi persaingan. Persepsi petani terhadap keunggulan produk kopi Arabika Gayo sebagian besar adalah setuju $(63,33 \%)$ dan di ikuti dengan netral (25\%). Hasil penelitian menunjukkan hasil produksi kopi Arabika Gayo petani cenderung tidak berbeda antara satu petani dengan petani atau dapat dikatakan tidak memiliki keunggulan/kelebihan. Hal tersebut dikarenakan, karena jumlah luas lahan yang dimiliki petani kopi Arabika Gayo rata-rata memiliki luas lahan yang sama. Selain itu, bibit yang digunaka juga dari sumber yang sama atau dari hasil perolehan cara yang sama. Umumnya, petani yang 


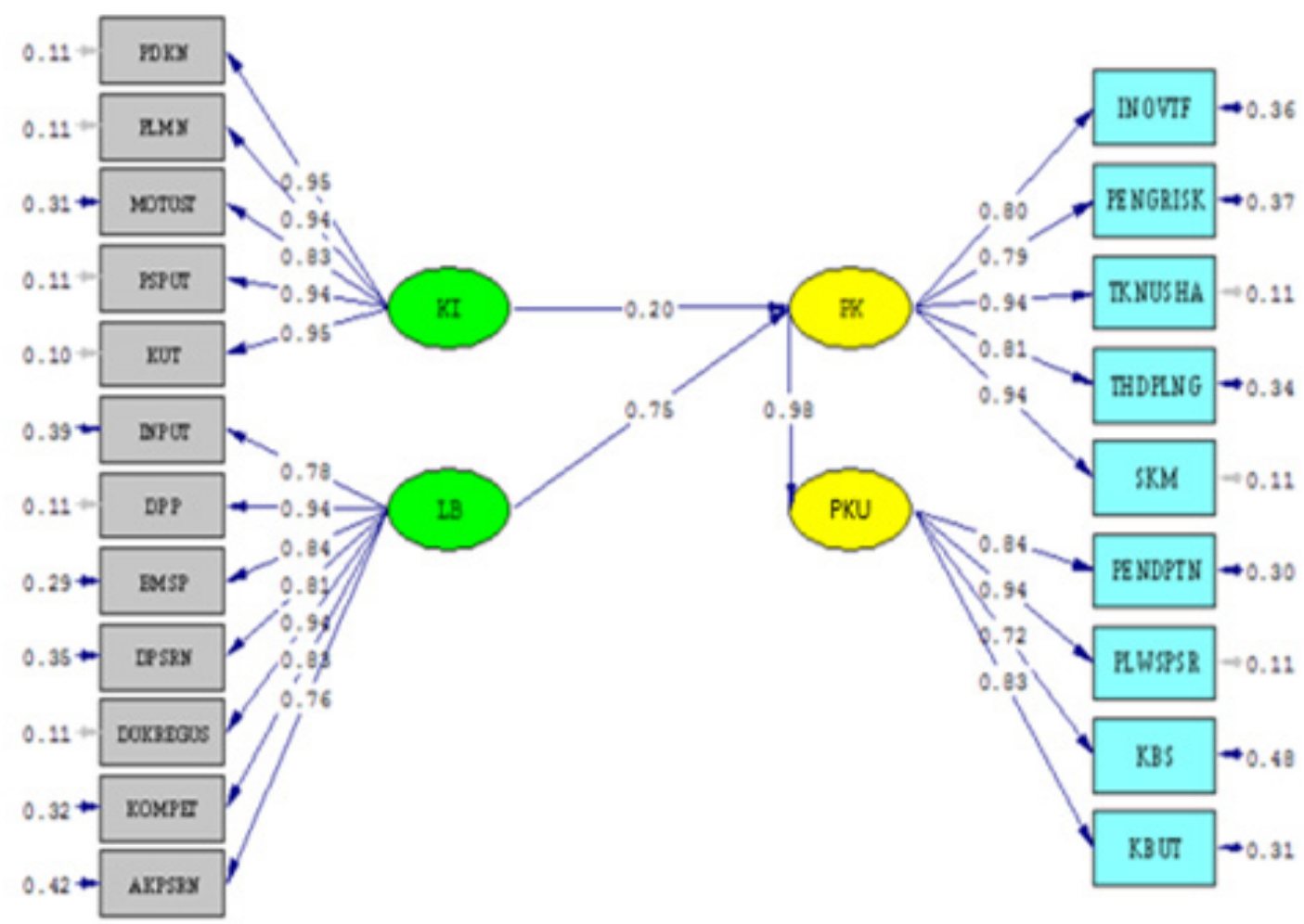

Chi-Square $=44.54, d f=136, p-v a l u e=1.00000$, RYSEA $=0.000$

Gambar 1. Standardized Solution Model Struktural Perilaku Kewirausahaan terhadap Perspektif Kinerja Usahatani Kopi Arabika Gayo Setelah Direspesifikasi di Kabupaten Bener Meriah Tahun 2015

mempunyai produk yang lebih unggul adalah petani yang memiliki keinginan dan kemampuan dalam berinovasi, misalnya dengan pembudidayaan yang homogen serta pembibitan dengan cara generatif. Ataupun petani dengan skala luas lahan yang lebih besar dari yaitu $\geq 1$ hektar dan memiliki modal usahatani yang lebih memadai.

\section{Komitmen Berusahatani}

Persepsi petani terhadap komitmen dalam berusahatani kopi Arabika Gayo menunjukkan sudah memadai.Hal ini ditunjukkan dari hasil jawaban responden memilih jawaban sangat setuju (70\%). Komitmen dalam berusahatani kopi Arabika Gayo ini ditunjukkan petani dengan memiliki pengalaman yang cukup lama dan kesetiaan petani dalam berusahatani kopi.Petani menjalankan usahatani kopi Arabika Gayo mulai dari turun temurun dan sudah menjadi mata pencaharian bagi mereka serta sudah menjadi budaya dan warisan leluhur yang harus dijaga karena sudah dari kecil tumbuh dan hidup dari tanaman kopi.

\section{Analisis Perilaku Kewirausahaan Petani Kopi Arabika Gayo dengan Pendekatan Structural Equation Models (SEM)}

Teori dan model dalam ilmu sosial dan perilaku (social and behavioral sciences) umumnya diformulasikan dengan menggunakan konsep-konsep teoritis yangtidak dapat diukur atau diamati secara langsung (Wijanto, 2008). Oleh sebab itu, adapun tujuan penyusunan model SEM lebih banyak bersifat teoritis sesuaidengan bidang terapan serta diarahkan nantinya untuk evaluasi kesesuaiannyadengan data yang diperoleh. Melalui analisis SEM, akan dapat diketahuihubungan-hubungan antar variabel berserta koefisiennya yang tidak dapat diukuratau diamati secara langsung namun dapat didekati melalui variabelvariabel indikatornya. Hasil analisis SEM terhadap estimasi model awal menunjukkan bahwa terjadi offending estimates (nilai-nilai estimasi yang melebihi batas yang dapat diterima) yaitu memiliki error varian negatif, standardized coefficients melebihi atau sangat dekat dengan satu dan memiliki t-value lebih kecil 
Tabel 1. Hasil Uji Kecocokan Model Respesifikasi

\begin{tabular}{lccc}
\hline \multicolumn{1}{c}{ Goodness of Fit Index } & Cut-of Value & Nilai Hasil Analisis & Keterangan \\
\hline$X^{2}$-Chi- square & Diharapkan Kecil $(<0,05)$ & 44,54 & Tidak Terpenuhi \\
Significaned $P$ & $\geq 0,05$ & 1,00 & Terpenuhi \\
RMSEA & $\leq 0,08$ & 0,000 & Terpenuhi \\
CMIN/DF & $\leq 2,0$ & 10076,52 & Terpenuhi \\
GFI & $\geq 0,90$ & 1,00 & Terpenuhi \\
CFI & $\geq 0,90$ & 1,00 & Terpenuhi \\
IFI & $\geq 0,90$ & 1,01 & Terpenuhi \\
PGFI & $\geq 0,50$ & 0,59 & Terpenuhi \\
RFI & $\geq 0,90$ & 0,99 & Terpenuhi \\
NNFI & $\geq 0,90$ & 1,01 & Terpenuhi \\
AGFI & $\geq 0,90$ & 0,99 & Terpenuhi \\
\hline
\end{tabular}

dari 1,96 sehingga dilakukan proses respesifikasi. Respesifikasi dilakukan dengan memanfaatkan saran yang ada pada modification indeks. Saran ini biasanya terdiri dari dua bagian yaitu: (1) menambahkan path (lintasan) diantara variabel manifes dengan laten; (2) menambahkan error covariances diantara dua buah error variances (Wijanto, 2008). Dalam penelitian ini yang digunakan adalah saran kedua. Diagram path estimasi pada model setelah proses respesifikasi terlihat pada Gambar 1.

\section{Uji Kecocokan Model (Goodness of Fit)}

Setelah model mengalami respesifikasi, maka selanjutnya model tersebut diujikembalikecocokannya. Pengujian ini dilakukan dengan mencocokkan kriteria ukuran kecocokan absolut, ukuran kecocokan inkremental, dan ukuran kecocokan parsimoni yang sudah ditetapkan.Adapun hasil goodness of fit statistics hasil estimasi model setelah direspesifikasi seperti pada Tabel 1.

Validitas model setelah dilakukan respesifikasi juga baik. Suatu variabel dikatakan mempunyai validitas yang baik terhadap konstruk atau variabel latennya jika nilai t-value $\geq 1,96$ pada taraf nyata $\alpha=0,05$ dan nilai standardized loading factor $\geq 0,3$ (Wijanto, 2008). Nilai standardized loading factor semuanya $\geq 0,3$ (Gambar 1) dan nilai t-value semuanya $\geq 1,96$ (Gambar 2). Validitas juga menunjukkan bahwa variabel pada model mampu mengukur apa yang seharusnya diukur atau model mampu menjelaskan hubungan-hubungan antar variabel.

Hasil uji reliabilitas terhadap model yang telah direspesifikasi menghasilkan reliabilitas konstruk atau construct reliability (CR) dan ekstrak varian atau variance extracted (VE) sebagian besar adalah baik (Tabel 2). Hal ini menunjukkan variabel-variabel indikator mempunyai konsistensi yang tinggi dalam mengukur konstruk latennya.

Hasil uji kecocokan model setelah respesifikasi menunjukkan tingkat reliabilitas yang baik.Ini dapat dilihat dari nilai Chi-square, Significant $P$ dan nilaiRMSEAyang lebih baik setelah mengalami respesifikasi. Oleh sebab itu, penilaian hubungan antar variabel SEM, baik hubungan antara variabel laten dengan indikator maupun antar variabel laten menggunakan nilai $\mathrm{R}^{2}$, koefisien, maupun t-hitung menggunakan model setelah respesifikasi.

\section{Analisis Model Struktural}

Pada bagian ini akan dibahas pengaruh antar variabel laten. Adapun pengaruh variabel tersebut antara lain pengaruh variabel karakteristik individu 


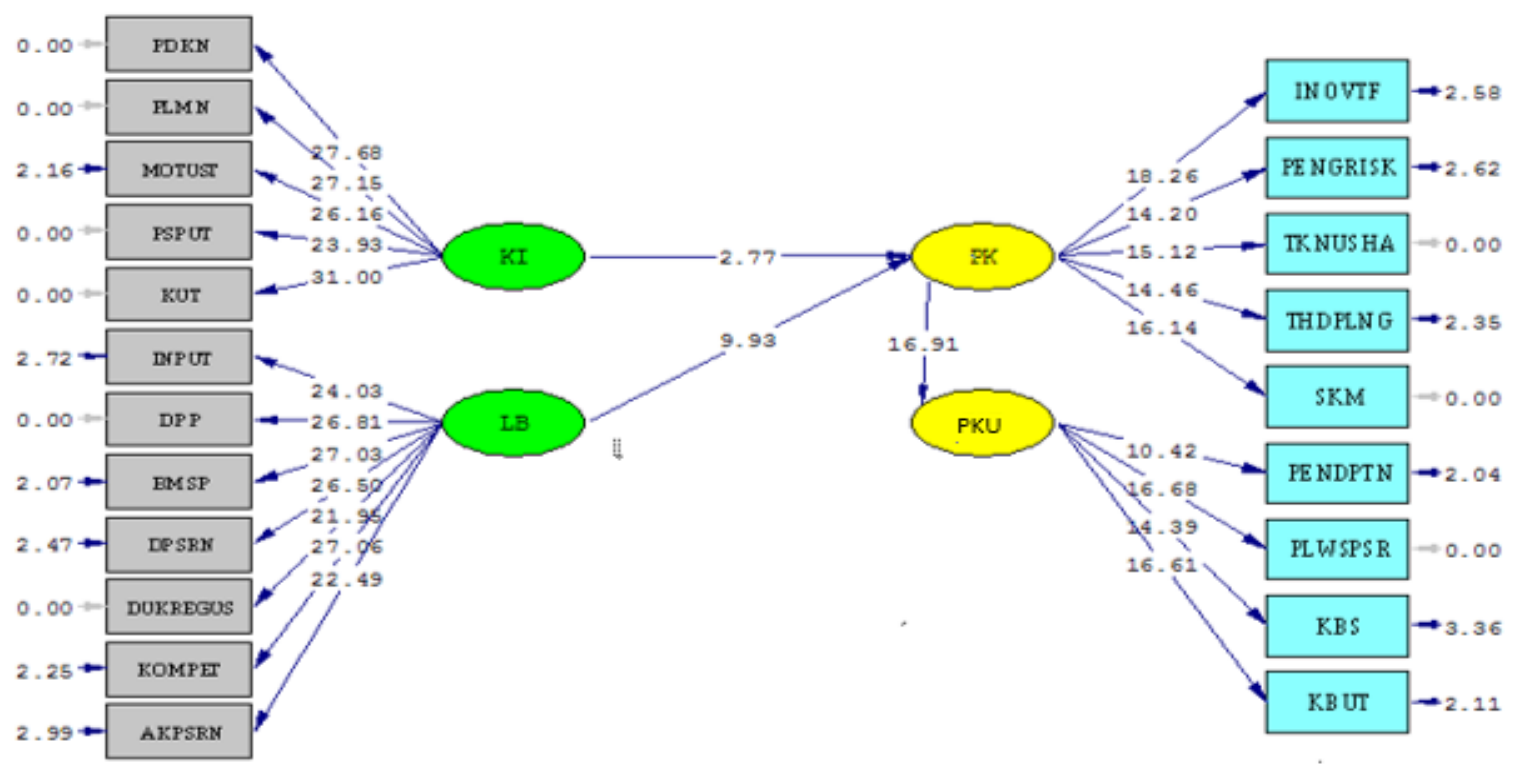

Chi-Square $=44.54, d f=136, \mathrm{p}$-value $=1.00000$, RMSEA $=0.000$

Gambar 2. Hasil Uji Validitas (T-Value) Model Pengarūh Perilaku Kewirausahaan Petani terhadap Perspektif Kinerja Usahatani Kopi Arabika Gayo di Kabupaten Bener Meriah Tahun 2015

petani terhadap perilaku kewirausahaan petani kopi Arabika Gayo, pengaruh lingkungan bisnis terhadap perspektif kinerja usahatani kopi Arabika Gayo dan pengaruh perilaku kewirausahaan petani terhadap perspektif kinerja usahatani kopi Arabika Gayo. Menurut Wijayanto (2008), evaluasi terhadap model struktural ini mencakup nilai koefisien, t-value, dan $\mathrm{R}^{2}$ (koefisien determinasi).Hasil dari evaluasi ini dirangkum pada Tabel 3.

\section{Pengaruh Karakteristik Individuterhadap Perilaku Kewirausahaan Petani Kopi Arabika Gayo di Kabupaten Bener Meriah}

Hasil penelitian menunjukkan bahwa karakteristik individu berpengaruh positif dan signifikan terhadap perilaku kewirausahaan dengan nilai koefisien korelasi sebesar 0,20 dan nilai t-hitung sebesar 2,77. Hal ini mengandung makna bahwa peningkatan faktor pendidikan, pengalaman, motivasi berusahatani, persepsi terhadap usahatani dan keinginan berusahatani akan meningkatkan perilaku kewirausahaan petani kopi Arabika Gayo, baik untuk menjadi wirausaha ataupun meningkatkan kinerja usahatani kopi Arabika Gayo agar semakin baik. Walaupun pada saat ini motivasi berusahatani cenderung rendah, tetapi dengan semakin tingginya keinginan petani dalam berusahatani kopi Arabika Gayo akan meningkatkan motivasi, meningkatkan inovatif, dan kemampuan mengambil atau menghadapi keputusan berisiko mereka untuk terus meningkatkan kinerja usahatani kopi Arabika Gayo. Oleh sebab itu, dengan adanya keinginan berusahtani yang tinggi merupakan salah satu cara yang dinilai efektif, baik untuk meningkatkan kinerja usahatani kopi Arabika Gayo ataupun menambah pengetahuan untuk diri mereka sendiri keinginan agar lebih maju.

Adapun variabel indikator yang paling dominan mengukur karakteristik individu petani adalah keinginan berusahatani dengan nilai muatan faktor $(\lambda)$ sebesar 0,95 . Hal ini dikarenakan para petani menganggap keinginan yang tinggi dalam berusahatani kopi memegang peranan penting, karena mengingat bahwa tanaman kopi Arabika Gayo merupakan tanaman tahunan yang membutuhkan waktu dan pemeliharaan yang baik.Kemudian diikuti oleh tingkat pendidikan, pengalaman, persepsi terhadap usahatani dan motivasi berusahatani. Variabel indikator yang 
Tabel 3. Hasil Nilai Koefisien dan T-hitung Model Struktural

\begin{tabular}{lccc}
\hline \multicolumn{1}{c}{ Hubungan antar variabel laten $($ Path $)$} & $\begin{array}{c}\text { Koefisien } \\
\text { korelasi }\end{array}$ & $\begin{array}{c}\text { Nilai } \\
\text { T-hitung }\end{array}$ & Kesimpulan \\
\hline Karakteristik individu $\rightarrow$ Perilaku kewirausahaan & 0,20 & 2,77 & Signifikan \\
Lingkungan bisnis $\rightarrow$ Perilaku kewirausahaan & 0,75 & 9,93 & Signifikan \\
$\begin{array}{l}\text { Perilaku kewirausahaan } \rightarrow \text { Perspektif kinerja } \\
\text { usahatani }\end{array}$ & 0,98 & 16,91 & Signifikan \\
\hline
\end{tabular}

Sumber: Hasil pengolahan data dengan LISREL 8.3, 2015

Keterangan: Nilai signifikan : *berhubungan nyata pada $\alpha 0.0$

paling sedikit mengukur karakteristik individu petani kopi Arabika Gayo adalah motivasi berusahatani dengan nilai muatan faktor $(\lambda)$ sebesar 0,83 . Hal ini dikarenakan petani menganggap kopi Arabika Gayo sebagai tanaman tradisi dan turun-temurun yang sudah di budidayakan sejak dari zaman dahulu.Petani menganggap motivasi tidak mempengaruhi perilaku untuk berwirausaha, tetapi lebih kepada keinginan yang tinggi dalam menjalankan usahanya.

Winardi (2002) menjelaskan bahwa ada sejumlah variabel penting yang digunakan orang untuk menerangkan perbedaan-perbedaan motivasi antar individu, antara lain umur, pendidikan, dan latar belakang keluarga.Motivasi untuk menjadi seorang wirausaha ataupun menjalankan usaha dipengaruhi oleh umur, pendidikan, dan latar belakang keluarga. Bagi sebagian orang, semakin meningkatnya umur, pendidikan, dan latar belakang keluarga sebagai wirausaha akan mempengaruhi keputusan seseorang untuk menjadi wirausaha ataupun tidak.

\section{Pengaruh Lingkungan Bisnis terhadap Perilaku Kewirausahaan Petani Kopi Arabika Gayo di Kabupaten Bener Meriah}

Berdasarkan Tabel 3, menunjukkan bahwa lingkungan bisnis berpengaruh positif dan signifikan terhadap perilaku kewirausahaan dengan nilai koefisien 0,75 dan nilai t-hitung 9,93. Nilai koefisien 0,75 ini memberikan pengertian bahwa pada penelitian ini terdapat pengaruh positif lingkungan bisnis terhadap perilaku kewirausahaan. Hal ini mengandung makna bahwa peningkatan faktor ketersediaan input, dukungan penyuluhan dan pelatihan, bantuan modal dan sarana produksi, dukungan promosi dan pemasaran, dukungan regulasi usaha, kekompakkan antar petani dan akses terhadap informasi pasar akan meningkatkan perilaku kewirausahaan petani kopi Arabika Gayo. Oleh sebab itu dengan semakin meningkatnya dukungan penyuluan dan pelatihan yang diterima petani kopi Arabika Gayo akan meningkatkan perilaku kewirausahaan petani dalam mengelola usahataninya dan pada akhirnya akan dapat meningkatkan kinerja usahatani kopi Arabika Gayo.

Adapun variabel indikator yang paling dominan mengukur lingkungan bisnis adalah faktor dukungan penyuluhan dan pelatihan dengan nilai muatan faktor $(\lambda)$ sebesar 0,94 . Hal ini dikarenakan para petani menganggap kebijakan pemerintah terhadap tingkat penyuluhan dan pelatihan dirasa cukup memadai, berupa pelatihan cara pembuatan pupuk kompos, budidaya, dan pengendalian hama. Kemudian diikuti oleh faktor dukungan regulasi usaha, bantuan modal dan sarana produksi, kekompakkan antar petani, dukungan promosi dan pemasaran, akses terhadap informasi pasar dan ketersediaan input yang akan meningkatkan perilaku kewirausahaan. Variabel indikator yang paling sedikit mengukur lingkungan bisnis adalah ketersediaan input dengan nilai muatan faktor $(\lambda)$ sebesar 0,78 . Hal ini dikarenakan petani menganggap ketersediaan input seperti bibit masih dilakukan dengan sistem stek dari tanaman sebelumnya yang sudah tua, sehingga dianggap kurang memadai.

Hasil persamaan menunjukan nilai koefisien determinan $\left(\mathrm{R}^{2}\right)$ pada persamaan perilaku kewirausahaan sebesar 0,85 . Artinya variansi pada faktor karakteristik individu petani dan lingkungan bisnis usahatani kopi Arabika Gayo secara bersamasama mampu menjelaskan $85 \%$ perubahan pada variabel laten perilaku kewirausahaan, sedangkan sisanya dipengaruhi oleh faktor lain yang tidak diukur dalam penelitian ini. 
Dengan demikian hasil penelitian ini menunjukan bahwa perilaku kewirausahaan dipengaruhi secara langsung oleh faktor karakteristik individupetanidanfaktorlingkunganbisnisyangberasal dari lingkungan, sebagaimana menurut Friederike and Smallbone (2011) perilaku kewirausahaan tidak bersifat mekanistik atau homogen dalam menghadapi tekanan eksternal tetapi dipengaruhi oleh interaksi yang kompleks dari faktor internal dan eksternal, sehingga terdapat heterogenitas dalam perilaku kewirausahaan karena tidak semua pengusaha bertindak dan bereaksi dengan cara yang sama dalam menghadapi tekanan kelembagaan. Heterogenitas tindakan pengusaha umumnya dipengaruhi oleh; (1) firm size (ukuran perusahaan), (2) The nature of venture (sifat usaha) dan (3) human capital (sumberdaya manusia).

\section{Pengaruh Perilaku Kewirausahaan Petani terhadap Perspektif Kinerja Usahatani Kopi Arabika Gayo di Kabupaten Bener Meriah}

Berdasarkan Tabel 3, menunjukan bahwa faktor-faktor yang berpengaruh langsung terhadap kinerja usahatani kopi Arabika Gayo adalah perilaku kewirausahaan dan faktor karakteristik individu dan lingkungan bisnis berpengaruh tidak langsung.

Variabel laten perilaku kewirausahaan berpengaruh langsung dan positif terhadap perspektif kinerja usahatani kopi Arabika Gayo dengan koefisien pengaruh sebesar 0,98 dan t-hitung 16,91, maka pengaruhnya signifikan pada taraf nyata $5 \%$. Dengan demikian peningkatan perilaku kewirausahaan akan meningkatkan perspektifkinerja usahatani kopiArabika Gayo. Hal tersebut dapat dijelaskan bahwa dengan berinovatif, tingkat pengambilan risiko, tekun berusaha, ketanggapan terhadap peluang dan kemandirian dalam menjalankan usahatani kopi Arabika Gayo pada akhirnya akan berpengaruh pada peningkatan kinerja usahatani. Sebagaimana hasil penelitian Fauzi (2006) dan Dirlanudin (2010) menujukan bahwa perilaku wirausaha berpengaruh langsung dan bernilai positif terhadap keberhasilan usaha, yaitu peningkatan jumlah pelanggan, kecenderungan loyalitas pelanggan, perluasan pangsa pasar, kemampuan bersaing, dan peningkatan pendapatan. Kinerja usaha tergantung pada tindakan (perilaku) yang diambil oleh pengusaha dan kondisi internal pribadi yang berpengaruh terhadap pengambilan keputusan bisnis.

Hasil penelitian menujukan bahwa kinerja usahatani akan meningkat sejalan dengan bertambahnya ketekunan, kemandirian, ketanggapan terhadap peluang, keberanian mengambil risiko, dan yang paling utama adalah dengan menumbuhkembangkan perilaku inovatif. Serta didukung dengan adanya bantuan dan upaya pemerintah melalui dinas setempat untuk menciptakan iklim usaha yang kondusif bagi perkembangan usahatani kopi Arabika Gayo. Sebagaimana menurut Krisnamurthi (2001) tantangan pembangunan agribisnis adalah untuk membangun kemampuan agribisnis memenuhi kebutuhan hidup pelakunya, terutama petani, dan masyarakat pada umumnya. Hal ini akan dapat dilakukan jika dapat dibangun keunggulan kompetitif pertanian berbasis keunggulan komparatifnya. Keunggulan kompetitif tersebut akan mampu dicapai jika faktor pendorong perkembangannya adalah inovasi dan kreativitas (innovation driven) yang sejalan dengan peran tenaga kerja berbasis pengetahuan (knowledge-based labour) yang lebih dominan.

\section{Kesimpulan}

Berdasarkan hasil penelitian, adapun kesimpulan dari penelitian ini menunjukkan bahwa karakteristik petani kopi Arabika Gayo secara umum adalah: (1) Tingkat usia petani kopi Arabika Gayo ratarata berada pada tingkat usia produktif yaitu usia 41 - 56 tahun, (2) tingkat pendidikan formal petani kopi Arabika Gayo mayoritas lulusan SMA, (2) mereka memiliki pengalaman yang cukup dalam berusahatani kopi Arabika Gayo, (3) usahatani kopi Arabika Gayo merupakan mata pencaharian utama, (4) umumnya modal usahatani didapatkan dari modal pribadi dan dirasa tidak memadai, dan (5) luas lahan yang dimiliki petani kopi Arabika Gayo rata-rata 0,5 - 1 hektar.

Karakteristik individu petani berpengaruh positif dan signifikan terhadap perilaku kewirausahaan. Hal ini menunjukan bahwa peningkatan pendidikan, pengalaman, motivasi berusahatani, persepsi terhadap usahatani dan keinginan berusahatani yang menjadi wirausaha akan meningkatkan perilaku kewirausahaan mereka. Sementara faktor lingkungan bisnis berpengaruh positif dan signifikan terhadap perilaku kewirausahaan. Hal ini dikarenakan dukungan pemerintah berupa penyuluhan dan pelatihan, bantuan modal dan saprodi, promosi dan pemasaran, regulasi usaha, serta ketersediaan informasi pasar dirasa cukup memadai sesuai dengan kebutuhan petani. 
Perilaku kewirausahaan berpengaruh positif dan signifikan terhadap perspektif kinerja usahatani kopi Arabika Gayo. Hal ini menunjukan bahwa perilaku kewirausahaan berperan penting dalam peningkatan kinerja usahatani, sehingga dengan ketekunan, ketanggapan terhadap peluang, inovatif, keberanian mengambil risiko dan kemandirian pada akhirnya akan berpengaruh terhadap perspektif kinerja usahatani kopi Arabika Gayo.

\section{Daftar Pustaka}

Adri. 1999. Analisis Kelembagaan dan Ekonomi Usahatani Kopi Arabika Organik Di Provinsi Daerah Istimewa Aceh [Tesis]. Bogor (ID): Institut Pertanian Bogor.

Burhanuddin. 2014. Pengaruh aktivitas kewirausahaan peternakan ayam broiler terhadap pertumbuhan ekonomi. [Disertasi]. Sekolah Pascasarjana, Institut Pertanian Bogor. Bogor.

Casson M, Yeung B, Basu A, dan Wadeson N. 2006. The Oxford Handbook of Enterprneurship. New York (US): Oxford University Press.

[Disbun] Dinas Perkebunan Provinsi Aceh. 2013. Prospek Pengembangan Kopi Arabika Gayo Di Kabupaten Aceh Tengah dan Bener Meriah. Aceh (ID) Disbun.

Delmar F. 1996. Enterpreneurial Behaviuor and Business Performance Dissertation The Economic Research Institut Stockhlom School of Economic, Stockholm.

Dirlanudin. 2010. Perilaku Wirausaha dan Keberdayaan Pengusaha Kecil Industri Agro: Kasus di Kabupaten Serang Provinsi Banten. [Disertasi]. Sekolah Pascasarjana, Institut Pertanian Bogor. Bogor.

[ICCRI] Indonesian Coffee and Cocoa Research Institute. 2008. Panduan Budidaya dan Pengolahan Kopi Arabika Gayo. Pusat Penelitian Kopi dan Kakao Indonesia. Jakarta (ID): Azrajens Mayuma.

Fatma Z. 2011. Analisis Fungsi Produksi dan Efisiensi Usahatani Kopi Rakyat di Aceh Tengah [Tesis]. Bogor (ID): Institut Pertanian Bogor.

Ferdinand A. 2002. Structural Equation Modelling dalam Penelitian Manajemen. BPUNDIP.

Fereidouni HG, Masron TA, Nikbin D, Amiri RE. 2010. Consequence of External Environment on Enterpreneurial Motivation in Iran. Asian Academy of Management Journal. 15(2): 175-196.
Friederike, Smallbone D. 2011. Institutional Perspectives on Enterpreneurial Behavior in Challenging Environtments. Journal of Small Business Management. Januari 2011. Vol 1, pg. 107-125. ABI/INFORM. Global.

Hadiyati E. 2011. Kreativitas dan inovasi berpengaruh terhadap kewirausahaan usaha kecil. Jurnal Manajemen dan Kewirausahaan. 13(1): 8-16.

Hasni, Dian. 2011. Designing a Quality Management Framework in Coffee Industry: a Literature Study of Improvement of Arabica Coffee as Specialty Coffee in Indonesia. [Tesis].University of Kassel and University of Applied Science Fulda Witzenhausen.

Jaya R. 2014. Rancang Bangun Rantai Pasol Kopi Arabika Gayo Berkelanjutan. [Disertasi]. Sekolah Pascasarjana, Institut Pertanian Bogor. Bogor.

Kasmir. 2006. Kewirausahaan. Jakarta(ID): PT Grafindo Persada.

Krisnamurthi B. 2001. Agribisnis. Bogor (ID): Yayasan Pengembangan Sinar Tani.

Mosher. 1987. Menggerakkan dan Membangun Pertanian. Jakarta (ID): Yasguna Jakarta.

Popkin SL. 1986. Petani Rasional. Terjemahan Mawi Sjahrir. Jakarta (ID): Lembaga Penerbit Padamu Negeri.

Priyanto SH. 2009. Mengembangkan Pendidikan Kewirausahaan di Masyarakat. Jurnal PNFI. 1(1): 57-82.

Puspitasri. 2013. Pengaruh perilaku kewirausahaan Petani anggrek terhadap kinerja usaha: Kasus di Kecamatan Gunung Sindur dan Parung, Kabupaten Bogor,dan Kecamatan Serpong, Kota Tangerang Selatan. [Tesis]. Bogor (ID): Institut Pertanian Bogor.

Putri A. 2013. Struktur dan Integrasi Pasar Kopi Arabika Gayo di Kabupaten Aceh Tengah dan Bener Meriah [Tesis]. Bogor (ID): Institut Pertanian Bogor.

Rauch A dan Frese M. 2007. Let's Put the Person Back into Entrepreneurship Research: A Meta-Analysis on the Relationship between Business Owner's Personality Traits, Business Creation, and Success. European Journal of Work and Organizational Psychology.16: 353-385.

Riyanti BPD. 2003. Kewirausahaan dari Sudut Pandang Psikologi Kepribadian. Jakarta (ID): PT.Grasindo.

Saputra A. 2012. Desain Rantai Pasok Agroindustri Kopi Organik di Aceh Tengah untuk Optimalisasi Balancing Risk [Tesis]. Bogor (ID): Institut Pertanian Bogor. 
Saragih B. 2010. Agribisnis: Paradigma Baru Pembangunan Ekonomi Berbasis Pertanian. Bogor (ID): PT. Penerbit IPB Press.

Sumantri B. 2013. Pengaruh jiwa kewirausahaan terhadap kinerja usaha wirausaha wanita pada industri pangan rumahan Di Bogor [Tesis]. Bogor (ID): Institut Pertanian Bogor.

TM Silitonga Cristina Mutiara. 2008. Analisis Keunggulan Bersaing Kopi Arabika Gayo Organik di Indonesia [Tesis]. Medan (ID): Universitas Terbuka UPBJJ Sumatera Utara.

Ucbasaran, Deni, Paul Westhead and Mike Wright. 2005. Habital Entrepreneurs. Oxford Handbook of
Entrepreneurship.Oxford University Press.

Yahmadi M. 2007. Rangkaian Perkembangan dan Permasalahan Budidaya dan Pengolahan Kopi di Indonesia. Asosiasi Eksportir Kopi Indonesia. Jawa Timur. 339p.

Yusnadi.1992.Adopsi Petani KopidalamPengembangan Perkebunan Kopi Rakyat [Tesis]. Bogor (ID): Institut Pertanian Bogor.

Winardi J. 2002. Motivasi dan Pemotivasian dalam Manajemen. Jakarta (ID): RajaGrafindo Persada.

Wijanto SH. 2008. Structural Equation Modelling dengan Lisrel 8.8: Konsep dan Tutorial. Yogyakarta (ID). Graha Ilmu. 